\title{
The Authenticity of the Notary's Authentic Deed on the Akad Murabaha on Syariah Financing in the Online Fiduciary Registration
}

\author{
D A Harahap ${ }^{1}$, W S Wahyuni ${ }^{2}$, U M Barus ${ }^{3}$ \\ Lecturer in Law Program, Universitas Medan Area, Sumatera Utara, Indonesia \\ ${ }^{1}$ dessyagustina86@yahoo.com
}

\begin{abstract}
Traditionally, the engagement of deed through a notary is executed directly, the party concerned comes directly to the notary. This can be seen in each opening of a notarial deed preceded by the phrase "has come to me". The phrase affirms that everyone who makes the deed, visits the notary directly and face to face. With the issuance of Government Regulation Number. 21 of 2015, it is possible to commit akad murabaha Fiduciary Warranty online. This research is a normative legal research. Normative legal research is a research that discusses the legal aspect, by conducting the library of research in terms of comparative law or legal history. This normative legal research use statutory approaches which are relevant to this legal research. Any authentic deed of a notary in the murabaha of an online fiduciary must be made by the parties concerned before the notary public. According to Islamic law, the authentic deed of a notary in the murabaha of fiduciary online can be justified as the pillars of the contract and does not contradict the Quran and Sunnah.
\end{abstract}

Keywords: Murabaha Legal Research, Deed

\section{INTRODUCTION}

The economic process that takes place in the community, is an inseparable part of national development, is one of the efforts to achieve a just and prosperous society based on Pancasila and the 1945 Constitution. In order to maintain and continue sustainable development, both government and the community, both individuals and legal entities, need large funds. Along with the increase in development activities, there is also a growing need for funding, with most of the funds needed to fulfill these needs through financing murabahahagreement, one of which can be done with a Fiduciary Warranty.

Murabahah is one of the forms of sale which is amanah (bai 'al-amanah) [1]. This is different from selling musawwamah/bargain. Murabahah is done between the seller and the buyer based on the price of the goods, the original purchase price of the seller known to the buyer and the profit taken by the seller is notified to the buyer, whereas the musawwamah is a transacted deal between the seller and the buyer at a price regardless of the original price of the goods [2]. The buying and selling which is also included in the sale and purchase of a trusty character is the sale and purchase of wadhi'ah, ie reselling at a low price (less than the original purchase price), and selling tauliyah, ie selling at the same price as the purchase price $[2]$. 
Traditionally, the engagement of deed through a notary is executed directly, the party concerned comes directly to the notary. This can be seen in each opening of a notarial deed preceded by the phrase "has come to me (telah datang kehadapan saya)". The phrase affirms that everyone who makes the deed, visits the notary directly and face to face. With the issuance of Government Regulation Number. 21 of 2015, it is possible to commit akad murabahah Fiduciary Warranty online without having to deal with a notary.

The Fiduciary Warranty Institution allows the Fiduciary Providers to control objects that are pledged as collateral, to conduct business activities financed from loans using the Fiduciary Warranty. Initially, objects that are objects of fiduciary are limited to the wealth of movable objects that are tangible in the form of equipment. However, in subsequent developments, objects that become fiduciary objects include wealth of movable objects that are intangible, or immovable objects.

Act Number 42 of 1999 concerning Fiduciary Warranty, the place of which the Fiduciary Warranty is located shall be registered. Registration of Fiduciary Warranty is to provide legal certainty to the parties concerned. Based on Article 37 paragraph (2) and Article 39 of Act Number 42 of 1999 concerning Fiduciary Warranty, the Fiduciary Registration Office is within the scope of the Ministry of Law and Human Rights with the working area of the entire territory of the Republic of Indonesia. In order to provide services to the public, based on Government Regulation Number 86 of 2000 concerning Procedures for Fiduciary Warranty Registration and Fiduciary Warranty Fee Making Cost, the Fiduciary Registration Office shall manually register Fiduciary Warranty which in its application has several obstacles, including the non-achievement of one-day service given the incoming request is very much beyond the ability of human resources and existing facilities. To overcome these problems, through Government Regulation Number 21 of 2015 concerning Procedures for Registration of Fiduciary Warranty and Fiduciary Warranty Fee Making Cost, an online Fiduciary Warranty registration service has established based on Article 3 to 10. The procedure begins with the fulfillment of administrative requirements, namely (refer to Article 3 Government Regulation number 21 of 2015). Then, the application is submitted no later than 30 days from the date of making the Fiduciary Warranty and proven by the proof of registration used as the basis for payment. Furthermore, the guarantee certificate will be issued with an electronic signature by the official at the Fiduciary Registration Office.

\section{LITERATURE REVIEW}

Islamic law in addition to full load of sociological content can not be denied to have also the theological dimension and this is what distinguishes Islamic law with the law in modern law science terminology, but the placement of the wrong way of view of the theological dimension it contains can lead to the assumption that the Islamic law is a sacred rule, even in certain circumstances people will be afraid to revalue the existing Islamic law rules, because they are psychologically burdened by the values of the sacredness, it is necessary to study that can lead to the correct view of the theological aspects in this Islamic law.

Islamic law is known as sya'riat. According to the terms, Shari'ah means the rules or laws that Allah revealed to govern all aspects of human life as servants of God, individuals, and subjects of the universe. Therefore the scope is limited to the laws governing human actions, and because they are the work of man he is not eternally applicable, subject to change from time to time and may differ from other places. This is seen in the schools called madhhab. Hence fiqih shows diversity in Islamic law [3]. 


\section{METHOD}

The problems in this research:How is the legal regulation regarding the validity of an authentic notary deed in an online Murabahah fiduciary agreement in accordance with the development of law and technology?

This research is a normative legal research. Normative legal research is a research that discusses the legal aspect, by conducting library research in terms of comparative law or legal history oriented to the applicable laws and regulations [4]. This normative legal research use statutory approaches which relevant to this legal research [5]. The data were analyzed using a comparative approach by conducting comparative law study which oriented to legal theory approach. The method used was comparing a certain legal system with another, which has more or less similarities, so that the similarities and differences between the legal systems were found [6]. The data were collected using a library research method by documenting relevant literature and provisions of legislation related to the problems to be answered in this research.

\section{RESULT and DISCUSSION}

The new arrangements contained in Government Regulation Number 21 of 2015, namely:

1. The Fiduciary Receiver, its power or representative shall be required to notify the removal of the Fiduciary Warranty. Notice of removal is free of charge.

2. The amount of the cost of making the Fiduciary Warranty Certificate shall be determined based on the value of guarantee which refers to the cost of making the deed as regulated in Article 36 paragraph (3) of Act Number 30 Year 2004 concerning Notary Position as amended by Act Number 2 of 2014 Amendment to Act Number 30 of 2004 concerning Position of Notary; and

3. The provisions concerning all data contained in the application of Fiduciary Warranty, application for repair of Fiduciary Warranty certificate, application for change of Fiduciary Warranty certificate, and notification of Fiduciary Warranty certificate deletion online and the retention of its physical document shall be the responsibility of the Fiduciary Receiver, the proxy or his representative.

In Article 2 of Government Regulation Number 21 of 2015 concerning the application for registration of Fiduciary Warranty, application for repair of Fiduciary Warranty certificate, application for change of Fiduciary Warranty certificate, and notification of Fiduciary Warranty certificate deletion submitted by Fiduciary Receiver, proxy or its representative to Minister through Fiduciary Warranty registration system online. However, notarial deeds are not done online, but only register the deed number that has been made by the notary manually. Therefore, any authentic notarial deed in the akad murabaha of online fiduciary must be made directly by the parties concerned before the notary public.

In the field of muamalah, known a principle of Islamic law of the principle of permissibility or mubah, this principle shows the ability to perform all civil relations (as a relationship muamalah) as long as the relationship is not prohibited by Al Quran and As Sunnah. This means that Islam provides a vast opportunity for those interested in developing new forms and kinds of civil relationships in accordance with the times and needs of mankind [7].

The position or validity of the authentic deed of the notary in the murabahah aggrement of online fiduciary based on Islamic law can be known through the rukun akad in Islam: [7]

1. Baligh, mature and sensible 
2. Ikrah, free from pressure or coercion from other parties

3. Object of akad justified by Islam, not only halal substances, but also useful

4. Objects must be clear and known to the parties

5. Can be handed over

6. Clear Ijab and Kabul. Akad can be done by oral and written, the most important is the consent with kabul is clear, and can be understood by both parties who do engagement [8].

Under the terms of Islam, the authentic deed of a notary in the murabaha of fiduciary online can be justified as long as it meets the rukun akad and is not contrary to the Qur'an and Sunnah.

\section{CONCLUSION}

Each authentic notary deed in an online fiduciary murabahah aggrement must be made directly by the parties concerned before the notary. According to Islamic law, an authentic notary deed in an online fiduciary murabahah aggrement to follow the development of law and technology can be justified as long as it fulfills the rukun akad and does not conflict with the Qur'an and Sunnah.

\section{REFERENCES}

[1] A. S. Sabiq, Fiqh as-Sunnah Jilid III. Beirut: Daral-Fikr.

[2] Wiroso, Jual Beli Murabahah. Yogyakarta: UII Press, 2005.

[3] H. M. Rasyidi, Hukum Islam dan Pelaksanaannya Dalam Sejarah. Jakarta: Bulan Bintang, 1976.

[4] H. Nawawi, Metode Penelitian Sosial. Surabaya: Laksbang Grafika, 2010.

[5] S. Soekanto and S. Mamudji, Penelitian hukum normatif suatu tinjauan singkat. Jakarta: Raja Grafindo Persada, 2003.

[6] Soeroso, Perbandingan hukum perdata. Jakarta: Sinar Grafika, 2005.

[7] N. R. Imaniyati and P. A. A. Putra, Hukum Bisnis: dilengkapi Dengan Kajian Bisnis Syariah. Bandung: Refika Aditama, 2017.

[8] T. A. Amal, Islam dan Tantangan Modernitas, Studi Stas Pemikiran Hukum Fazlur Rahman. Bandung: Mizan, 1989. 